\title{
Role of gonadotrophins and ovarian steroids in the development of mouse follicles in vitro
}

\author{
N. Spears ${ }^{1}$, A. A. Murray ${ }^{1}$, V. Allison ${ }^{1}$, N. I. Boland ${ }^{1}$ and \\ R. G. Gosden ${ }^{2}$ \\ ${ }^{1}$ Department of Physiology, University Medical School, Teviot Place, Edinburgh EH8 9AG, UK; and \\ ${ }^{2}$ Division of Obstetrics and Gynaecology, University of Leeds, Clarendon Wing, Leeds General In Ermary, \\ Leeds LS2 9NS, UK
}

\begin{abstract}
A whole follicle culture system has been used to investigate the actions of gonadotrophic hormones, oestrogen and progesterone in the regulation of follicular development and steroidogenesis. Recombinant human FSH was required for the growth of preantral follicles and for Graafian morphogenesis, whereas recombinant LH was ineffective. While pure FSH was sufficient for growth and morphogenesis, production of oestrogen was greater when androstenedione or LH was present in combination with FSH, confirming that there is a two-cell mechanism for oestradiol production in the mouse follicle. When an antiserum to oestrogen or to progesterone or an oestrogen receptor antagonist were added to the culture medium, there was no significant effect on either follicular growth or oestradiol production. Thus, physiological concentrations of oestradiol are not needed for follicle development, although a role cannot be completely ruled out. In conclusion, the obligatory role of FSH was demonstrated. It appears to be sufficient for follicle development even in the absence of $\mathrm{LH}$, and the paracrine or autocrine effects of oestradiol and progesterone, if any, appear to be minor in the mouse ovary.
\end{abstract}

\section{Introduction}

Ovarian follicles consist of layers of granulosa and thecal cells enveloping a central oocyte and, as such, represent the fundamental unit for ovarian function, namely, the production of eggs and hormones. When cultured whole, follicles are able to develop and produce oestradiol in a manner that closely resembles growth and secretion in vivo (Gosden et al., 1993) and are able to produce fertile oocytes (Spears et al., 1994). Culture of whole follicles provides an opportunity to investigate the actions of gonadotrophic hormones and the role of paracrine and autocrine factors at each stage in a controlled environment. The opportunity to investigate follicular biology in vitro has been taken in this study to explore the value of this model for investigating gonadotrophin requirements for growth and to gain new information about the follicular endocrinology of an important laboratory species: the mouse.

Much of our current understanding of follicle biology rests on studies of rat ovaries, either in vivo or using isolated follicular cells. It has become clear that there is a two-cell mechanism for oestrogen biosynthesis in which neither the granulosa cells nor the theca cells are independently capable of producing normal amounts of oestrogen (Dorrington et al., 1975; Armstrong et al., 1979). The gonadotrophic hormones, LH and FSH, have complementary effects: LH stimulates the production of androgens by theca cells which are aromatized in the granulosa layer under the influence of FSH. This model

Revised manuscript received 21 April 1997. holds in a number of species, although exceptions are known in which cell autonomous production of oestradiol occurs, such as in the pig (Evans et al., 1981), which makes it important to clarify the biology of such an important experimental model as the mouse.

This paper reports the actions of pure gonadotrophins on follicles growing in vitro. It also tests the hypothesis that FSH alone is sufficient to support follicle growth, whereas LH is needed to stimulate maximal oestradiol output. This study also investigated steroid action on follicle growth and confirmed earlier assumptions about the role of progesterone, while throwing doubt on the role of oestrogen as a paracrine mediator.

\section{Materials and Methods}

\section{Animals}

Twenty-four-day-old $\mathrm{C} 57 \mathrm{BL} / 6 \times \mathrm{CBA} \mathrm{Ca} \mathrm{F}_{1}$ hybrid, female mice were housed in a temperature- and light-controlled room on a $14 \mathrm{~h}$ light: $10 \mathrm{~h}$ dark photoperiod and were provided with food and water ad libitum. Female hypogonadal mice ( $h p g / h p g)$ produced by mating heterozygous parents were selected on the basis of their phenotype at postpubertal ages and were maintained under similar conditions.

\section{Isolation and culture of follicles}

The mice were killed by cervical dislocation and their ovaries were removed to watchglasses containing Leibovitz L-15 
medium (Gibco-BRL, Irvine) and $3 \mathrm{mg} \mathrm{BSA} \mathrm{ml}^{-1}$ (Fraction $\mathrm{V}$, Sigma, Poole) at $37^{\circ} \mathrm{C}$. Preantral mouse follicles were isolated by microdissection at a diameter of $185 \pm 15 \mu \mathrm{m}$ using fine needles and pipetted individually into $96-\mathrm{V}$-well microtitre plates (Bibby-Sterilin Ltd, Stone) in $20 \mu \mathrm{l}$ of $\alpha$-minimal essential medium (Gibco-BRL, Renfrew) under $50 \mu \mathrm{l}$ mineral oil, according to the method of Boland et al. (1993), and based on an earlier method developed by Nayudu and Osborn (1992). The medium was supplemented with $10 \mu \mathrm{g}$ human transferrin $\mathrm{ml}^{-1}$ (Sigma) and 5\% serum from hypogonadal mice. Gonadotrophins were added to some of the wells at a concentration of either 1 or $5 \mathrm{iu} \mathrm{ml}^{-1}$. These were either human pituitary FSH (NIH-FSH, National Hormone and Pituitary Program, Bethesda, $\mathrm{ML})$, which contained approximately $1 \%(\mathrm{w} / \mathrm{v}) \mathrm{LH}$ as an impurity, pure recombinant $\mathrm{FSH}(\mathrm{rFSH})$ or recombinant $\mathrm{LH}$ $(\mathrm{rLH})$ (Serono Laboratories, Geneva). Follicles were transferred to new wells with fresh media each day: media from the previous day were then frozen for future measurement of oestradiol. No attempts were made to stimulate ovulation with $\mathrm{LH}$, although this culture system is known to allow the development of potentially fertile oocytes (Boland et al., 1993; Spears et al., 1994).

\section{Measurement of oestradiol}

After follicle transfer, a sample of medium from the incubation of the previous day was removed from each well (see above), frozen, and later analysed immunoenzymatically for oestradiol using an ELISA method (Serono Diagnostics, Woking). The inter- and intra-assay coefficients of variation were both $\leq 5 \%$ and the sensitivity was $\leq 18 \mathrm{pmol} \mathrm{l}^{-1}$.

\section{Follicle growth and morphology}

Follicle growth was monitored by measuring follicle diameter on each day of culture using a precalibrated ocular micrometer at $\times 40$ magnification. Data presented include measurements from all follicles still viable on the final day of culture. About $20 \%$ of follicles burst or became atretic, usually early in the culture period (probably due to damage on the day of dissection). Measurements from such follicles were not included in the analyses. No differences were found among the percentages of such follicles across treatments.

In Expts I, 3 and 4, the DNA accumulation by follicles was also assessed using a fluorescent dye, Hoechst 33258 (bisbenzimidazole; Sigma), by measurement in a microtitre plate fluorometer (Dynatech, Billinghurst) (Boland and Gosden, 1994).

Preovulatory follicles were classified as having (i) a diameter $\geq 400 \mu \mathrm{m}$; (ii) a large antral cavity; (iii) an eccentrically placed oocyte-cumulus complex; (iv) no visible signs of atresia (that is, dark patches of dead granulosa cells).

\section{Experiment 1: DNA content of developing follicles}

Forty-four follicles were dissected for each experiment, four of which were frozen immediately and stored at $-20^{\circ} \mathrm{C}$ for DNA analysis. The remaining 40 follicles were cultured in control medium as described above (day 0 ). On each successive day of culture (days 1-5), four representative, non-atretic follicles were also frozen for DNA analysis.

\section{Experiment 2: effects of gonadotrophic hormones on follicle growth and steroidogenesis}

Follicles were cultured in media containing either human pituitary FSH (NIH-FSH, with $1 \%(w / v)$ LH contamination), or rFSH or lacking FSH. The effects of culturing follicles in NIH-FSH ( 1 iu $\mathrm{ml}^{-1}$ ) and $\mathrm{rFSH}\left(5 \mathrm{iu} \mathrm{ml}^{-1}\right.$ ) were compared (Expt 2a). Follicles were then cultured in the presence of NIH-FSH, rLH only ( 1 or $5 \mathrm{iu} \mathrm{ml}^{-1}$ ) or in the absence of gonadotrophins (Expt 2b). Follicles were then cultured with $\mathrm{rFSH}$ ( 1 or $5 \mathrm{iu} \mathrm{ml}^{-1}$ ), plus or minus supplements of

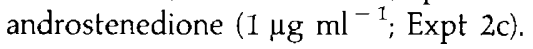

\section{Experiment 3: effect of oestrogen on follicle development}

Anti-oestrogen antibodies were used to neutralize oestrogens secreted by the cultured follicles. The high titre antiserum was raised by immunizing castrated Suffolk cross-bred sheep with oestrone-6-carboxymethyl-oxime conjugated to egg albumin (Land et al., 1982). No significant crossreactivity of the antibody occurs with either progestagens or androgens (Webb et al., 1985).

In an additional experiment, follicles were cultured with a potent, competitive and highly specific oestrogen receptor antagonist, ICI 182,780 (Wakeling et al., 1991). The molar concentration of antagonist in the medium was approximately 1000 times greater than the concentration of oestradiol accumulated by control follicles in the medium in $24 \mathrm{~h}$ $\left(4.95 \pm 0.4 \mathrm{nmol} \mathrm{l}^{-1}\right)$.

Fifty preantral follicles were dissected for each experiment. All follicles were cultured with $\mathrm{I}$ iu NIH-FSH $\mathrm{ml}^{-1}$. In addition, ten follicles were cultured with 3\% anti-oestradiol antiserum from day 2 of culture, and another ten follicles were incubated with $5 \mu \mathrm{mol}$ oestrogen receptor antagonist $\mathrm{l}^{-1}$. A further ten follicles were incubated with FSH and diethylstilbestrol (DES, I $\mu \mathrm{g} \mathrm{ml}^{-1}$; Sigma). DES was chosen as it did not crossreact with the antibody but did give a specific oestrogenic effect. As the oestradiol antibody and antagonist were diluted in sheep serum and alcohol, respectively, ten control follicles were cultured with medium containing 3\% sheep serum, and another ten follicles served as a vehicle control with $1 \mu \mathrm{l}$ ethanol $\mathrm{ml}^{-1}$ in addition to the standard supplements. Treatments commenced $24 \mathrm{~h}$ after the beginning of culture (day 1); any degenerating follicles were discarded at this time.

\section{Experiment 4: effect of progesterone on follicle development}

For this experiment, an anti-progesterone antiserum was used to neutralize progesterone secreted by the cultured follicles. The high titre antiserum was raised in a sheep by injecting progesterone 11 $\alpha$-hemisuccinyl-BSA (Flint et al., 1974). The crossreactivity of this antibody with either androgens or oestrogens was negligible. Twenty preantral follicles were dissected for each experiment. Ten follicles were 


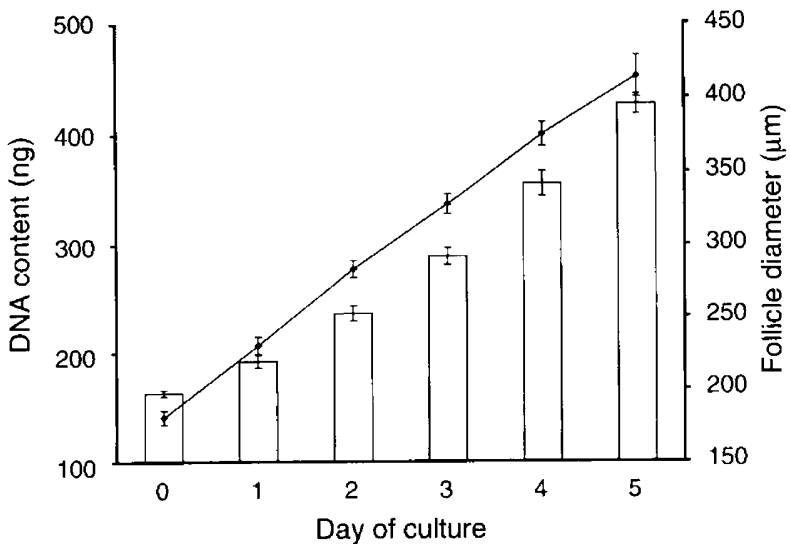

Fig. 1. Changes in the DNA content $(\square)$ and diameter $(\bullet)$ of mouse follicles grown from the preantral to preovulatory stage over a period of 5 days in vitro in the presence of pituitary FSH.

cultured with $3 \%$ antiserum from day 1 , and ten were cultured in control medium containing normal sheep serum and the standard supplements.

\section{Histological preparations}

Cultured follicles were prepared for examination by light microscopy after fixing overnight in $5 \%(\mathrm{w} / \mathrm{v})$ paraformaldehyde. Follicles were then embedded in LR White resin (Taab, Aldermaston) and $2 \mu \mathrm{m}$ sections were cut and stained with haematoxylin and eosin.

\section{Statistical analysis}

Each experiment was repeated three times, with the exception of Expt I which was performed in duplicate. Probability values $(P)$ between the different groups were determined by the unpaired Student's $t$ test and analysis of variance.

\section{Results}

\section{Experiment 1: DNA content of developing follicles}

During the culture period, approximately $80 \%$ of the follicles developed from the mid-preantral to large preovulatory stage with a fully expanded antral cavity and without visible signs of atresia. The DNA content of the developing follicles increased linearly 20-fold with increasing follicle diameter over the 5 days of culture $(r=0.85 ; P<0.001)$ (Fig. 1). In view of the high correlation, follicle diameter alone was used in subsequent experiments for monitoring growth, although DNA content was measured at the end of the culture period in some experiments, to verify that expansion in follicle size reflected an increase in the number of cells.

\section{Experiment 2: effects of gonadotrophic hormones on follicle growth} and steroidogenesis

These studies demonstrated the roles of gonadotrophic hormones on follicle growth and steroidogenesis. Pituitary FSH
( $1 \mathrm{iu}$ ) and rFSH (5 iu) produced almost identical rates of growth (both producing maximal stimulation), although these units are not strictly comparable (Expt 2a; Figs 2 and 3). Indeed, Graafian morphology can be obtained in the presence of $1 \mathrm{iu} r F S H ~ \mathrm{ml}^{-1}$ alone (A. A. Murray, unpublished). Oestradiol production, which was increased by days 4 and 5, was nevertheless substantially and significantly lower with the pure recombinant hormone preparation than with the NIH-FSH which has some degree of LH contamination.

In the absence of gonadotrophins, follicles grew initially at the same rate as in medium containing FSH, but were significantly lagging by day $2(P<0.05)$ (Expt 2 b; Fig. 4 ). Three to four days later they were shrunken and presumably atretic. At no time did they form an antral cavity. Follicles grown in rLH only ( 1 or $5 \mathrm{iu}$ ) fared little better since they remained preantral, and hardly changed in size after day 2. Follicles cultured in pituitary FSH had produced substantial amounts of oestradiol by day 5 , whereas concentrations remained close to the limits of detection in the other groups (Fig. 4).

Addition of androstenedione to medium containing $\mathrm{rFSH}$ produced an increase in follicular growth throughout the culture period $(P<0.05)$. A more marked increase was obtained in respect of oestradiol production compared with unsupplemented medium $(P<0.01)$ (Expt 2c; Fig. 5). The production of oestradiol by control follicles treated with rFSH was, in Expt $2 c$, much higher than in Expt 2a (Fig. 2), indicating considerable variability between cultures and the necessity to include controls in every experimental replicate.

\section{Experiment 3: effects of anti-oestrogen antiserum and oestrogen receptor antagonist}

In contrast with Expt 2, neither the anti-oestrogen antiserum (data not shown) nor the oestrogen receptor antagonist (Fig. 6) affected the rate of follicle growth in Expt 3. In both cases, the DNA contents on day 5 were similar to that of the controls. Supplementation of DES to the medium containing FSH did not affect the final sizes of follicles: $393 \pm 5 \mu \mathrm{m}$ and $381 \pm 7 \mu \mathrm{m}$, for controls and DES-treated follicles, respectively.

Oestradiol production showed the characteristic increase on days $3-5$ but the amounts produced per follicle were unaffected by the presence of the oestrogen receptor antagonist (Fig. 6). No measurements of production rates in the presence of anti-oestrogen antiserum were made because of the possibility of antibody interference in the assay.

\section{Experiment 4: effects of anti-progesterone antiserum}

Follicles grew at similar rates in medium with or without this antiserum (Fig. 7), and the DNA contents on day 5 did not differ significantly $(655 \pm 22 \mathrm{ng}$ per follicle and $660 \pm 18 \mathrm{ng}$ per follicle, respectively). Similar numbers of follicles grew to antral sizes in the medium containing antiserum and they produced comparable amounts of oestradiol as they did in control medium (Fig. 7).

\section{Discussion}

Studies of whole follicles isolated in vitro demonstrate more clearly than in any other model that the follicle is a 


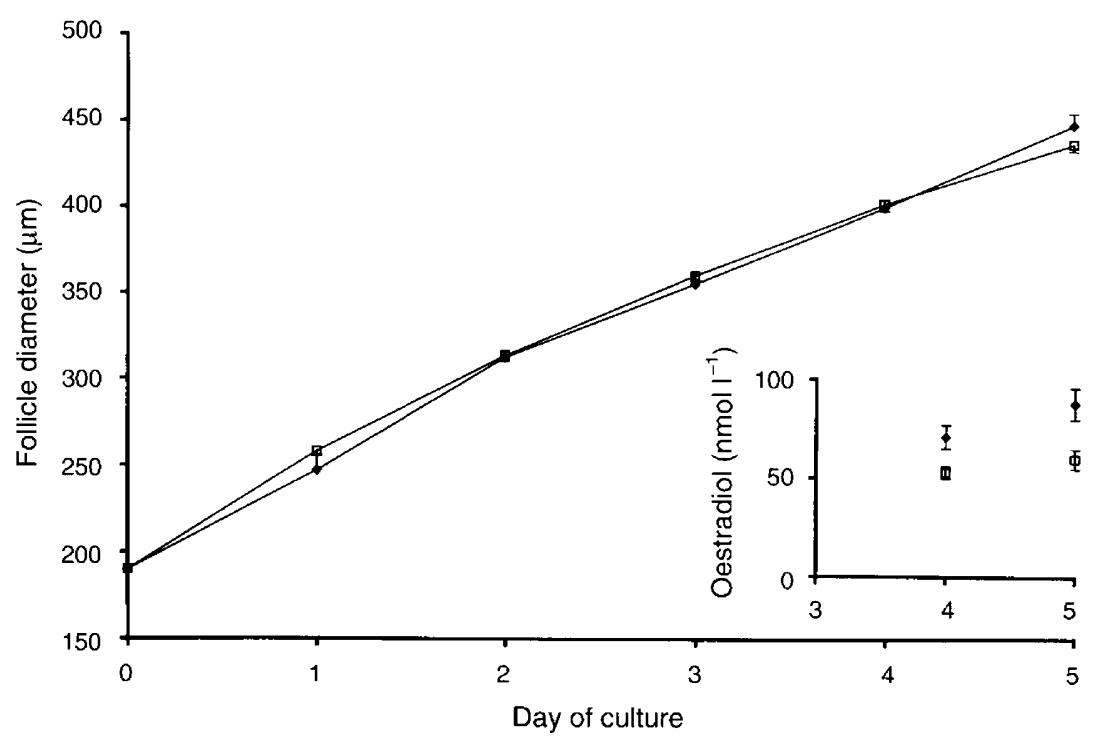

Fig. 2. Comparison of the effects of $5 \mathrm{iu} \mathrm{rFSH} \mathrm{ml}^{-1}$ (.) and pituitary I iu NIH-FSH ml ${ }^{-1}$ (-) on the rates of growth and $24 \mathrm{~h}$ production of oestradiol (inset) by mouse follicles grown in vitro for 5 days from the preantral stage.

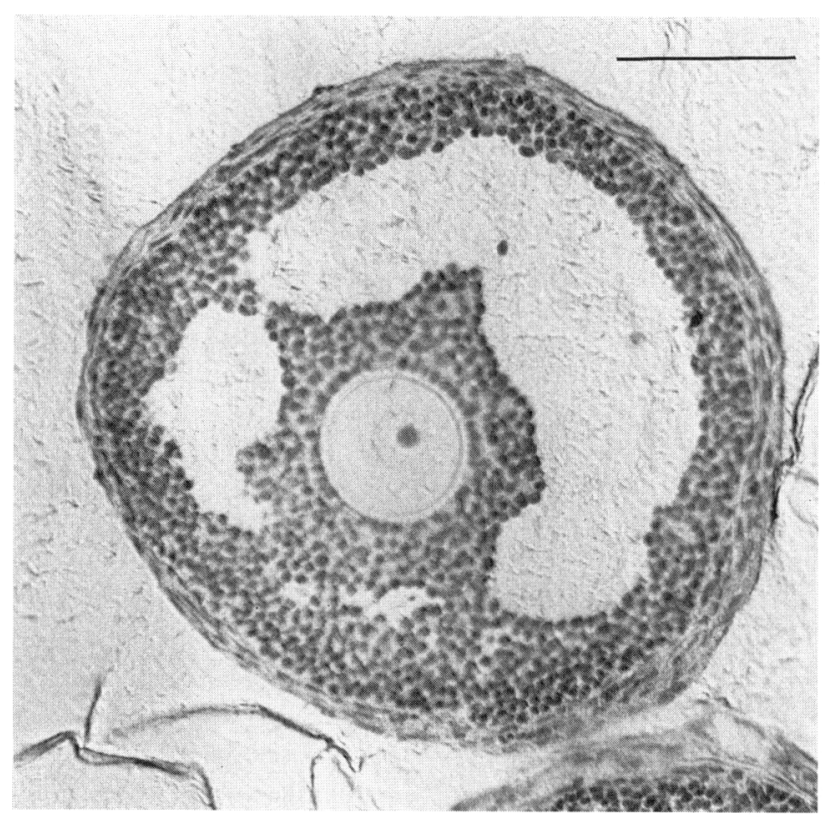

Fig. 3. Photomicrograph of a mouse follicle cultured in rFSH alone. Scale bar represents $100 \mu \mathrm{m}$

developmental unit. The follicle is able to grow, differentiate and produce oestradiol in the absence of other ovarian cell types, provided it is stimulated by FSH in a nutrient medium. These studies confirm and extend a large body of evidence showing a differential role of the gonadotrophins, and demonstrate for the first time that the 'two-cell theory' of oestradiol production applies in the mouse as in several other species (Hillier et al., 1995).

Follicles were unable to develop fully in the absence of FSH and degenerated at the stage when an antrum is incipient, similar to the in vitro results of Nayudu and Osborn (1992) and
Hartshorne et al. (1994) and to follicle development in transgenic mice lacking FSH (Kumar et al., 1997). LH was unable to stimulate Graafian morphogenesis. Therefore, the culture system provides a useful model for investigating the physiology of the poorly understood process of atresia. When pure FSH was used to stimulate follicle development to the preovulatory stage, only small quantities of oestradiol were produced, compared with control groups in that same experiment in which $\mathrm{LH}$ was also present. A high degree of variation in oestradiol concentrations has been found consistently from culture to culture, suggesting that comparisons across cultures 


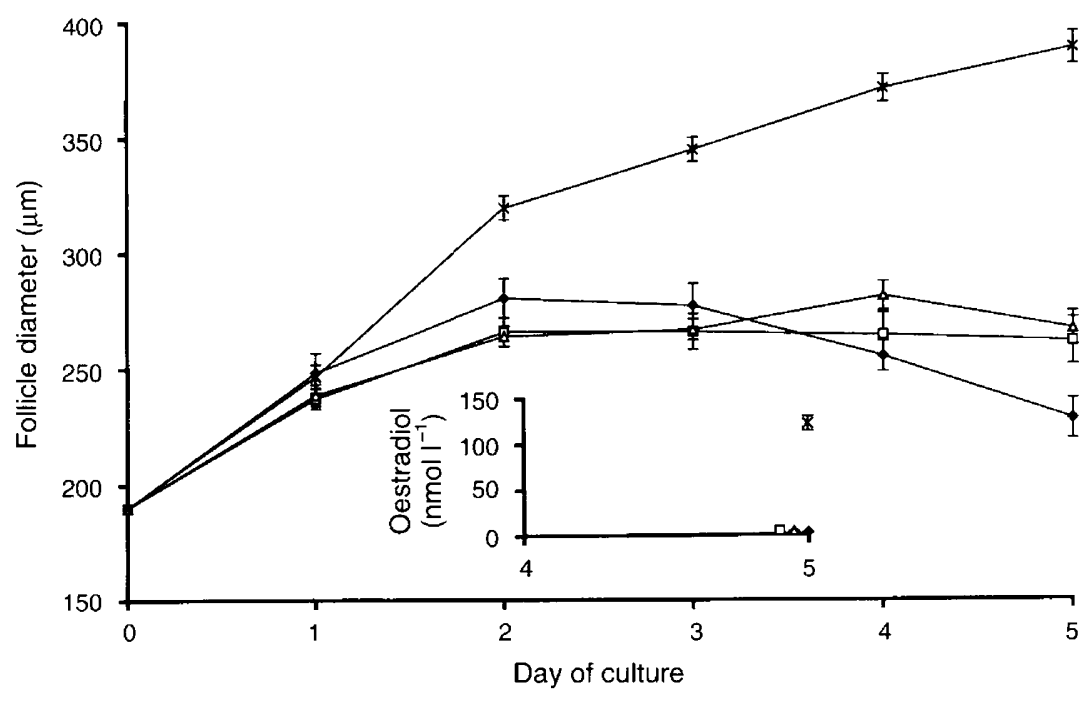

Fig. 4. Comparison of the effects of medium containing FSH $(x), 1$ iu rLH $(\ulcorner), 5$ iu rLH $(\Delta)$ or no gonadotrophins $(\bullet)$ on the rates of growth and $24 \mathrm{~h}$ production of oestradiol (inset) by mouse follicles grown in vitro for 5 days from the preantral stage.

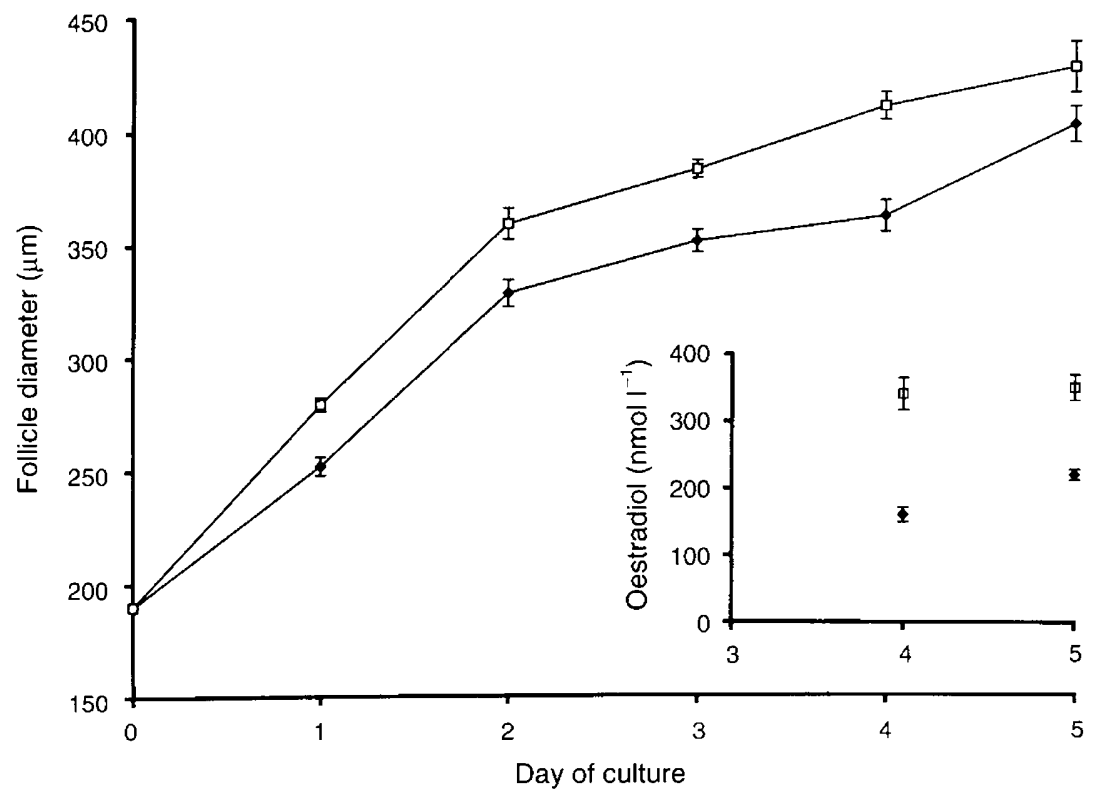

Fig. 5. Comparison of the effects of addition of androstenedione with recombinant FSH (二) and recombinant FSH alone $(\bullet)$ on the rates of growth and $24 \mathrm{~h}$ production of oestradiol (inset) by mouse follicles grown in vitro for 5 days from the preantral stage.

are of relatively little value: control groups are needed within each experiment for valid comparisons. The oestradiol concentration decreased when follicles cultured in serum from hypogonadal animals were compared with those cultured in serum from hypophysectomized mice (N. Spears, unpublished). This finding suggests either that serum concentrations of LH that are below the limits of detection in hypogonadal mice (H. M. Charlton, personal communication) can stimulate steroidogenesis, or the involvement of other endocrine factors (for example, hypoadrenocorticism in hypophysectomized mice) (Ben-Chetrit, 1996). The results in vitro confirmed those of hypogonadotrophic patients and animals, which have shown that FSH must be combined with LH for the synthesis of normal amounts of follicular oestradiol (Eshkol and Lunenfeld, 1967; Couzinet et al., 1988; Mannaerts et al., 1991, 1994; Karnitis et al., 1994; Schoot et al., 1994; Balasch et al., 1995; Zelinski-Wooten et al., 1995). Cortvrindt et al. (1996) have demonstrated the ability of $\mathrm{rFSH}$ to support oocyte growth and maturation and oestradiol production from a similar follicle culture but in which the follicular membrane is not kept intact.

The effects of incubation with pituitary FSH suggest that trace quantities of LH are sufficient to stimulate production of 


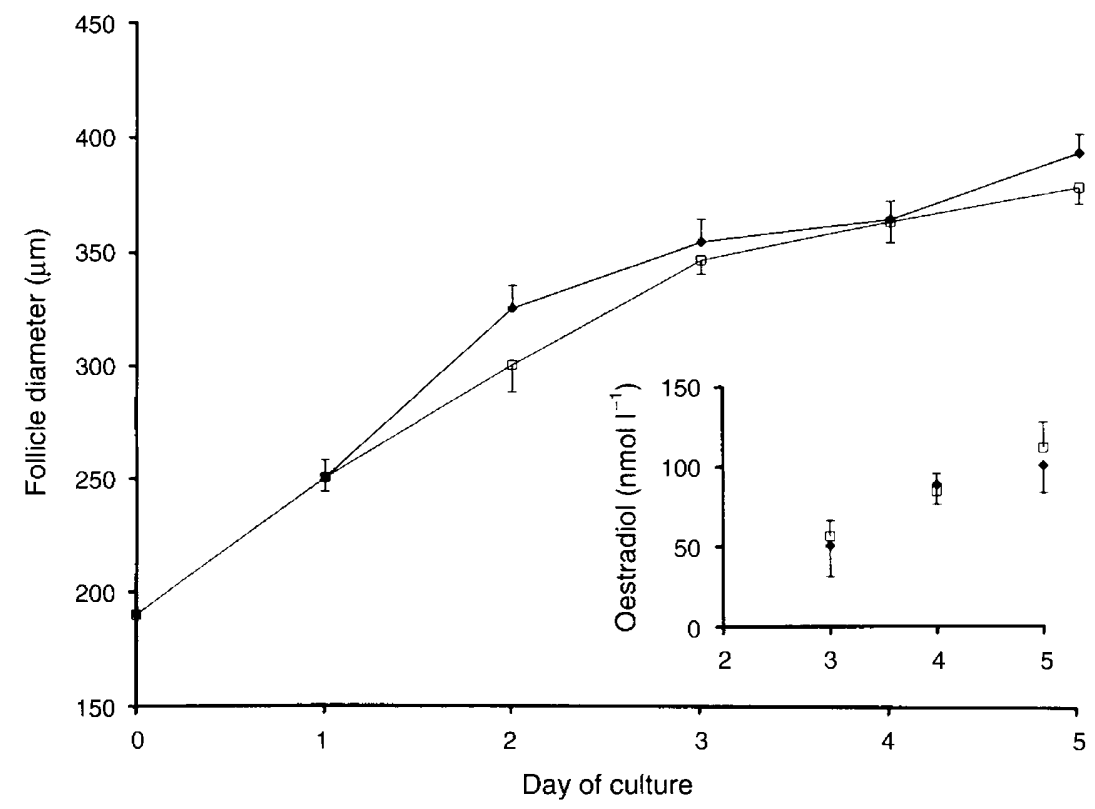

Fig. 6. Variations in the rate of growth and production of oestradiol (inset) by mouse follicles grown in vitro for 5 days from the preantral stage with $(\square)$ and without $(\bullet)$ a highly potent and specific oestrogen receptor antagonist (ICI 182,780).

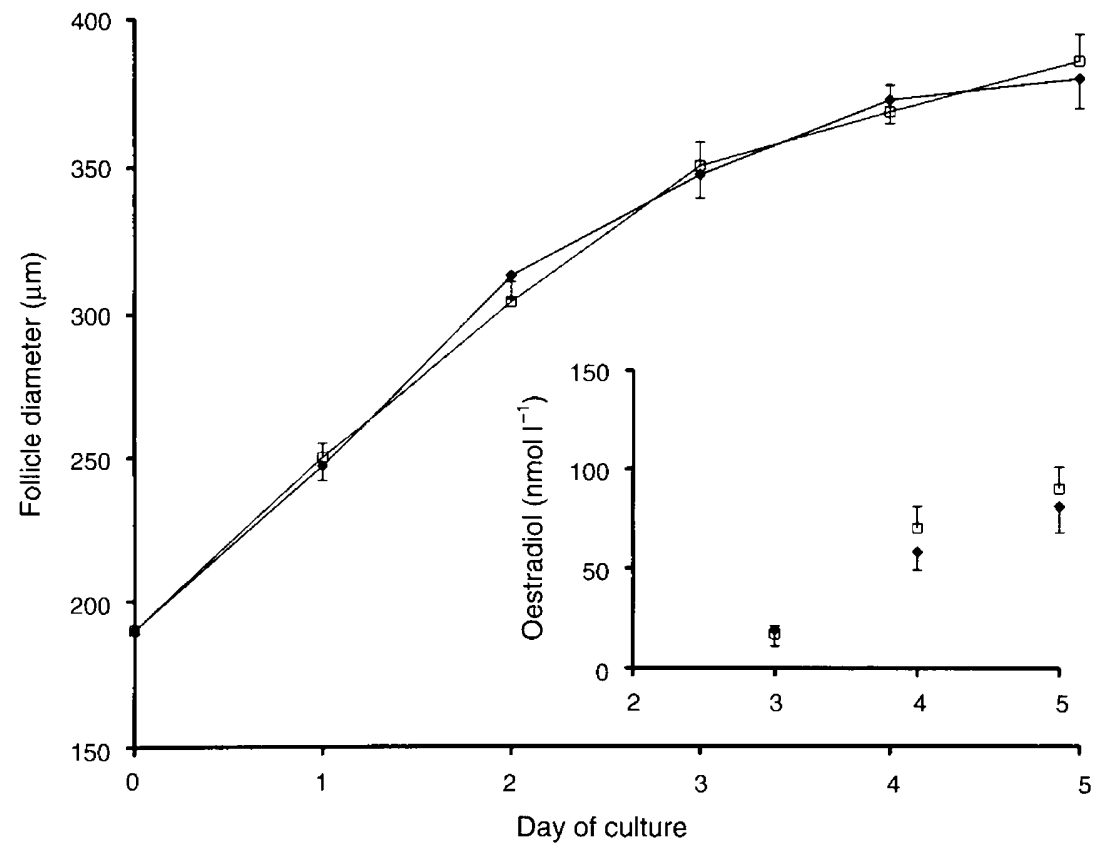

Fig. 7. Variations in the rate of growth and production of oestradiol (inset) by mouse follicles grown in vitro for 5 days from the preantral stage with $(\square)$ and without $(\bullet)$ anti-progesterone antibody.

oestradiol, which presumably depends on augmented androgen synthesis in the theca layer. Treatment with LH alone was unable to promote oestradiol production. Paracrine effects may account, in part, for the oestradiol production of follicles cultured in $\mathrm{rFSH}$ alone: FSH stimulates inhibin production by granulosa cells which then acts on the thecal cells to stimulate increased LH-induced release of androgens and P450 aromatase and cytochrome P450 17a-hydroxylase (Gray et al., 1995, 1996; Hillier et al., 1995; Smyth et al., 1995).

Supplementing the medium with androstenedione increased oestradiol on each of the days tested, but failed to give a proportionate increase on day 5. The weak response of preovulatory follicles may be a sign that aromatization was already maximally stimulated or that the effects of androgens 
on oestradiol production vary at different developmental stages (Harlow et al., 1988; Hillier et al., 1988). The better growth obtained by addition of androstenedione to pure FSH indicated a possible stimulatory role for androgens, which was the subject of a separate investigation (Murray et al., 1997).

In theory, the production of progesterone by granulosa cells could provide an additional loop in the process of steroidogenesis. For example, antibodies to this hormone inhibited oestrogen synthesis when granulosa and theca cells were co-cultured, presumably because progesterone had been converted to androgens in the theca (Lui and Hsueh, 1986). The present results provided no evidence that this hypothetical mechanism plays any physiological role, as follicle growth was unaffected when the addition of progesterone antibody substantially reduced the amount of progesterone available. This should not be surprising, as growing follicles produced undetectable amounts of progesterone in this culture system until the preovulatory stage (N. Spears, A. A. Murray, V. Allison, N. I. Boland and R.G. Gosden, unpublished), similar to the situation found in vivo before the mid-cycle LH surge (Zeleznik and Resko, 1980).

The ability of ovarian steroids to influence the development of follicles through paracrine or autocrine mechanisms is controversial, and immunoneutralization of follicular steroids or competitive inhibition of oestrogen binding to their receptor in culture provides an opportunity to test this theory. Clearly, large doses of oestrogens can stimulate follicular growth in hypophysectomized rats (Williams, 1940; Richards, 1980; Hsueh, 1986). Furthermore, disruption of the oestradiol receptor by gene targeting produces a dearth of antral follicles and anovulation in homozygous mice (Lubahn et al., 1993), although it is not clear to what extent this effect is due to intraovarian effects. However, there is experimental evidence in vivo and in vitro that high concentrations of oestrogen are not mandatory for preovulatory development in some species (Schoot et al., 1992; Mannaerts et al., 1994; Boland and Gosden, 1994; Zelinski-Wooten et al., 1994), while in others, inhibitory effects of oestrogen have been described (Dierschke et al., 1994). In the presence of either anti-oestrogen antibodies or a highly potent and reversible receptor antagonist (Wakeling et al., 1991), follicles grew at a normal rate in vitro and appeared morphologically indistinguishable from controls. The antagonist did not affect the production of follicular oestradiol, which appears to rule out any major self-priming effect on aromatization or cellular proliferation. As further evidence that any autocrine effects of oestrogen are minor or absent in mice, supplementation of oestradiol in the absence of gonadotrophins in the culture medium was unable to support normal follicle growth to the antral stage (N. Spears, A. A. Murray, V. Allison, N. I. Boland and R. G. Gosden, unpublished). This resuit is consistent with the findings of Wang and Greenwald (1993), who administered synthetic oestrogen each day to hypophysectomized mice and were unable to obtain full development. In conclusion, follicular development in this species under the conditions studied does not require the concentrations of oestrogens normally found in gonadotrophin-stimulated follicles. However, it should be noted that oocytes were not examined at the end of this study and, therefore, the possibility cannot be excluded that oestrogens stimulate oocyte development.
By implication, the main actions of oestrogen in the oestrous cycle are probably extra-follicular, although this study does not completely rule out a local role for oestrogen, such as the stimulatory effect of oestrogen on rat granulosa cell proliferation (Rao et al., 1978). Oestrogen receptors are present in the granulosa cells and oocyte, but their abundance appears to vary between species and, consequently, extrapolations from one to another may be invalid ( $\mathrm{Wu}$ et al., 1992; Kawashima and Greenwald, 1993; Moudgal et al., 1996). However, it remains possible that, despite a large excess of the oestrogen receptor antagonist, trace amounts of oestradiol had bound to the cognate receptor and that these were sufficient to maintain follicular development or, alternatively, that oestrogen was acting other than through its receptor.

These studies demonstrate the value of follicle growth in vitro for investigating mechanisms of follicle development and secretion. Since follicles can be grown from early preantral to the preovulatory stage, it is possible to explore the mechanisms of follicle development at almost every stage. In these studies, it has been possible to demonstrate the overriding importance of FSH during follicle development, and that $\mathrm{LH}$ has little role beyond increasing the production of oestradiol, until ovulation. Antibodies were used to investigate the role of steroid metabolism on follicle development. Similarly, the system can be used to explore paracrine-autocrine mechanisms (for example, see Smyth et al., 1994). Finally, the results of gonadotrophin deprivation have shown that FSH appears to be an essential survival factor: in the absence of FSH, follicles became clearly atretic. Therefore, the culture system can be valuable either as a model of follicular atresia, or for investigating the role of paracrine factors.

This work was generously supported by the Wellcome Trust and the Medical Research Council. The authors would like to thank V. Ingham for helping to prepare the manuscript, the Medical Microbiology Transgenic Unit, University of Edinburgh for supplying the hybrid mice and $\mathrm{H}$. M. Charlton for hypogonadal mice. The authors gratefully acknowledge gifts from A. E. Wakeling (Zeneca Pharmaceuticals, Macclesfield) of the oestrogen receptor antagonist, of recombinant gonadotrophins hFSH and hLH, from C. Howles (Serono, Geneva), and R. Webb (Rostin Institute, Midlothian) for steroid antibodies. Pituitary FSH (AFP-5720D) was obtained through NHPP, NIDDK, NICHHD, USDA. N. Spears is supported by The Royal Society.

\section{References}

Armstrong DT, Goff AK and Dorrington JH (1979) Regulation of follicular oestrogen biosynthesis. In Ovarian Follicular Development and Function pp 169-182 Eds AR Midgley, Jr and WA Sadler. Raven Press New York

Balasch J, Miro F and Burzaco I (1995) The role of LH in human follicle development and oocyte fertility; evidence from IVF in a woman with long-standing hypogonadotrophic hypogonadism and using rhFSH Human Reproduction 10 1678-1683

Ben-Chetrit A, Gotlieb L, Wong PY and Casper RF (1996) Ovarian response to recombinant human FSH in LH-depleted women: examination of the two cell, two gonadotropin theory Ferfility and Sterility $65711-717$

Boland NI and Gosden RG (1994) Effects of EGF on the growth and differentiation of cultured mouse ovarian follicles Journal of Reproduction and Fertility $101369-374$

Boland NI, Humpherson DG, Leese HJ and Gosden RG (1993) Pattern of lactate production and steroidogenesis during growth and maturation of mouse ovarian follicles in vitro. Biology of Reproduction 48 798-806 
Cortvrindt R, Smitz J and Van Steirteghem AC (1996) In vitro maturation, fertilization and embryo development of immature oocytes from early preantral follicles from prepubertal mice in a simplified culture system Human Reproduction 11 2656-2666

Couzinet B, Lestrat N, Brailly S, Forest M and Schaison G (1988) Stimulation of ovarian follicular maturation with pure FSH in woman with gonadotropin deficiency Joumal of Clinical Endocrinology and Metabolism 66 552-556

Dierschke DJ, Chaffin CL and Hute RJ (1994) Role and site of estrogen action in follicular atresia Trends in Endocrine Metabolism 5 2.15-219

Dorrington JH, Moon YS and Armstrong DT (1975) Oestradiol-17 $\beta$ biosynthesis in cultured granulosa cells from hypophysectomized immature rats: stimulation by follicle stimulating hormone Endocrinology 97 1328-1335

Eshkol A and Lunenfeld B (1967) Purification and separation of FSH and LH from human menopausal gonadotrophin III effects of a biologically apparently pure FSH preparation on ovaries and uteri of intact immature mice Acta Endocrinology 54 91-95

Evans G, Dobias M, King GJ and Armstrong DT (1981) Estrogen, androgen and progesterone biosynthesis by theca and granulosa of preovulatary follicles in the pig Biology of Reproduction 25 673-682

Flint APF, Anderson ABM, Patten PT and Turnbull AC (1974) Control of utero-ovarian venous prostaglandin $\mathrm{F}$ during labour in the sheep: acute effects of vaginal and cervical stimulation Journal of Endocrinology 63 67-87

Gosden RG, Boland NI, Spears N, Murray AA, Chapman M, Wade JG, Zohdy N and Brown $\mathbf{N}$ (1993) The biology and technology of follicular oocyte development in vitro. Reproductive Medicine Review 2 129-152

Gray SA, Mannan MA and O'Shaughnessy PJ (1995) Development of cytochrome P450 aromatase mRNA levels and enzyme activity in ovaries of normal and hypogonadal mice Journal of Molecular Endocrinology 14 295-301

Gray SA, Mannan MA and O'Shaughnessy PJ (1996) Development of cytochrome P450 17-alpha-hydroxylase (P450c17) mRNA and enzyme activity in neonatal ovaries of normal mice Journal of Molecular Endocrinology 17 $55-60$

Harlow CR, Shaw HJ, Hillier SG and Hodges JK (1988) Factors influencing follicle stimulating hormone-responsive steroidogenesis in marmoset granulosa cells: effects of androgens and the stage of follicular maturity Endocrinology 122 2780-2787

Hartshorne GM, Sargent IL and Barlow DH (1994) Growth rates and antrum formation of mouse ovarian follicles in vitro in response to FSH, relaxin, cyclic AMP and hypoxanthine Human Reproduction 9 1003-1012

Hillier SG, Harlow CR, Shaw HJ, Wickings EJ, Dixson AF and Hodges JK (1988) Cellular aspects of preovulatory folliculogenesis in primate ovaries Human Reproduction 3 507-511

Hillier SG, Smyth CD, Whitelaw PF, Miro F and Howles CM (1995) Gonadotrophin control of follicular function Hormonal Research $\mathbf{4 3} 216-223$

Hsueh AJW (1986) Paracrine mechanisms involved in granulosa cell differentiation Clinical Endocrinology and Metabolism 15 117-134

Karnitis VT, Towson DH, Friedman CI and Danforth DR (1994) Recombinant human FSH stimulates multiple follicular growth but minimal estrogen production in $\mathrm{GnRH}$ antagonist-treated monkeys; examining the role of $\mathrm{LH}$ in follicular development and steroidogenesis Journal of Clinical Endocrinology and Metabolism $7991-97$

Kawashima M and Greenwald GS (1993) Comparison of follicular estrogen receptors in rat, hamster and pig Biology of Reproduction 48 172-179

Kumar TR, Wang Y, Lu N and Matzuk MM (1997) FSH is required for ovarian follicle maturation but not male fertility Nature Genetics 15 201-204

Land RB, Morris BA, Baxter G, Fordyce M and Forster J (1982) Improvement of sheep fecundity by treatment with antisera to gonadal steroids journal of Reproduction and Fertility 66 625-634

Lubahn DB, Moyer IS, Golding TS, Cowse JF, Korach KS and Smithies O (1993) Alteration of reproductive function but not prenatal sexual development after insertional disruption of the mouse oestrogen receptor gene Proceedings of the National Academy of Sciences USA 9011 162-11 166

Lui $Y-X$ and Hsueh AJW (1986) Synergism between granulosa and thecainterstitial cells in oestrogen biosynthesis by gonadotrophin-treated rat ovaries: studies on the two-cell two-gonadotrophin hypothesis using steroid antisera Biology of Reproduction 35 27-36

Mannaerts B, de Leeuw R, Geden J, Schuurs A and Kloosterboer H (1991) Comparative in vitro and in vivo studies on the biological characteristics of recombinant human FSH Endocrinology 129 2623-2630

Mannaerts B, Uilenbroek J, Schot P and de Leeuw R (1994) Folliculogenesis in hypophysectomised rats after treatment with rhFSH Biology of Reproduction $5172-81$

Moudgal NR, Shetty G, Selvarak N and Bhatnagar AS (1996) Use of a specific aromatase inhibitor for determining whether there is a role for oestrogen in follicle/oocyte maturation, ovulation and preimplantation embryo development Journal of Reproduction and Fertility Supplement 50 69-81

Murray AA, Gosden RG, Allison V and Spears N (1998) Effect of androgens on the development of mouse follicles growing in vitro. Journal of Reproduction and Fertility $11327-33$

Nayudu PL and Osborn SM (1992) Factors influencing the rate of preantral and antral growth of mouse ovarian follicles in vitro. Journal of Reproduction and Fertility 95 349-362

Rao MC, Midgley AR and Richards JS (1978) Hormonal regulation of ovarian cellular proliferation Cell 14 71-78

Richards JS (1980) Maturation of ovarian follicles: actions and interactions of pituitary and ovarian hormones on follicular cell differentiation Physiological Reviews 60 51-89

Schoot DC, Coellingh Bennink HJT, Mannaerts BMJL, Lamberts SWJ, Bouchard P and Fauser BCJM (1992) Human recombinant follicle-stimulating hormone induces growth of preovulatory follicles without concomitant increase in androgen and oestrogen biosynthesis in a woman with isolated gonadotrophin deficiency Journal of Clinical Endocrinology and Metabolism $\mathbf{7 4}$ 1471-1473

Schoot DC, Harlin J, Shoham F, Mannaerts BMJL, Lahlou N, Bouchard P and Bennink HJTC (1994) Recombinant human FSH and ovarian response in gonadotrophin-deficient women Human Reproduction 9 1237-1242

Smyth CD, Gosden RG, McNeilly AS and Hillier SG (1994) Effect of inhibin immunoneutralization on steroidogenesis in rat ovarian follicles in vitro. Journal of Endocrinology 140 437-443

Smyth CD, Miro F, Howles AM and Hillier SG (1995) Effect of LH on FSH-activated paracrine signalling in rat ovary Human Reproduction 10 $33-39$

Spears N, Boland NI, Murray AA and Gosden RG (1994) Mouse oocytes derived from in vitro grown primary ovarian follicles are fertile Human Reproduction $9527-532$

Wakeling AE, Dukes M and Bowler J (1991) A potent specific pure antioestrogen with clinical potential Cancer Research 51 3867-3873

Wang $X$ and Greenwald GS (1993) Synergistic effects of steroids with FSH on folliculogenesis, steroidogenesis and FSH- and hCG-receptors in hypothysectomized mice Journal of Reproduction and Fertility $99403-413$

Webb R, Baxter G, McBride D, Nordblom GD and Shaw MPK (1985) The measurement of testosterone and oestradiol- $17 \beta$ using iodinated tracers and incorporating an affinity chromatography extraction procedure Journal of Steroid Biochemistry 23 1043-1051

Williams PC (1940) Effect of stilboestrol on the ovaries of the hypophysectomized rat Nature $145 \quad 388-389$

Wu T-CJ, Wang L and Wan Y-JY (1992) Expression of oestrogen receptor gene in mouse oocyte and during embryogenesis Molecular Reproduction and Development 33 407-412

Zeleznik AJ and Resko JA (1980) Progesterone does not inhibit gonadotrophininduced follicular maturation in the female rhesus monkey Endocrinology 106 $1820-1826$

Zelinski-Wooten MB, Hess DL, Wolf DP and Stouffer RL (1994) Steroid reduction during ovarian stimulation impairs oocyte fertilization but not folliculogenesis in rhesus monkeys Fertility and Sterility 61 1147-1155

Zelinski-Wooten MB, Hutchison JS, Hess DL, Wolf DP and Stouffer RL (1995) FSH alone supports follicle growth and oocyte development in GnRH antagonist-treated monkeys Human Reproduction 10 1658-1666 